Erratum

\title{
Erratum: Michael A. Picker; et al.; H-NS, Its Family Members and Their Regulation of Virulence Genes in Shigella Species. Genes 2016, 7, 112
}

\author{
Michael A. Picker and Helen J. Wing * \\ School of Life Sciences, University of Nevada Las Vegas, Las Vegas, NV 89154-4004, USA; \\ pickerm3@unlv.nevada.edu \\ * Correspondence: helen.wing@unlv.edu; Tel.: +1-702-895-5382
}

Received: 14 June 2017; Accepted: 14 June 2017; Published: 15 June 2017

The authors wish to make the following change to their paper [1]. In the Acknowledgments Section, the sentence "The IPTG-inducible pCA24N ( $-g f p)$ plasmid and derivatives were used to express each of the hns family members found in Shigella flexneri 2a strain 2457T. We acknowledge National BioResource Project: E. coli at NIG for sending us these ASKA clones [89]." should be inserted after "We thank ... . . . editorial comments". The added reference [89] is "89. Kitagawa, M.; Ara, T.; Arifuzzaman, M.; Ioka-Nakamichi, T.; Inamoto, E.; Toyonaga, H.; Mori, H. Complete set of ORF clones of Escherichia coli ASKA library (a complete set of E. coli K-12 ORF archive): Unique resources for biological research. DNA Res. 2005, 12, 291-299."

We apologize for any inconvenience caused to the readers by this omission. The manuscript will be updated and the original will remain online on the article webpage.

\section{Reference}

1. Picker, M.A.; Wing, H.J. H-NS, Its Family Members and Their Regulation of Virulence Genes in Shigella Species. Genes 2016, 7, 112. [CrossRef] [PubMed]

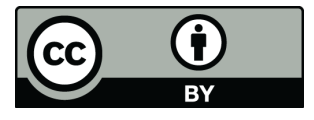

(C) 2017 by the authors. Licensee MDPI, Basel, Switzerland. This article is an open access article distributed under the terms and conditions of the Creative Commons Attribution (CC BY) license (http:// creativecommons.org/licenses/by/4.0/). 